УДК 618.3:616.992.282:615.282

DOI 10.11603/24116-4944.2019.2.10921

(C). Є. Марченко, Т. П. Яремчук

Львівсъкий національний медичний університет ілені Данила Галищького

\title{
ЗАСТОСУВАННЯ ВІТЧИЗНЯНОГО КЕТОКОНАЗОЛУ ДЛЯ ДОПОЛОГОВОЇ ПІДГОТОВКИ ВАГІТНИХ ІЗ ГЕНІТАЛЬНИМ КАНДИДОЗОМ
}

Мета дослідження - поліпшення перинатальних наслідків вагітності та зменшення кількості акушерських ускладнень у вагітних із хворобами піхви на основі застосування вітчизняного кетоконазолу (лівагін-М, Україна) в допологовій підготовці вагітних із генітальним кандидозом та вивчення його впливу на піхвовий мікробіом.

Матеріали та методи. Матеріалом дослідження були показники результатів бактеріологічного дослідження піхвового секрету 32 вагітних із генітальним кандидозом та 15 здорових вагітних у 36-38 тижнів вагітності. Методи дослідження: клінічні, біохімічні, УзД, бактеріологічні та медико-статистичні.

Результати дослідження та їх обговорення. У хворих на вагінальний кандидоз вагітних було виявлено високі титри

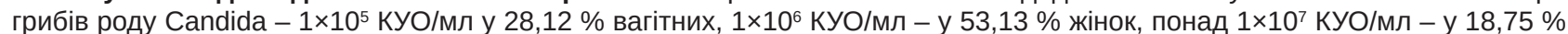
обстежених при різкому зниженні рівня лактобацил - менше $1 \times 10^{6} \mathrm{KУO/мл} \mathrm{у} \mathrm{всіх} \mathrm{пацієнток.} \mathrm{Після} \mathrm{10-денного} \mathrm{курсу} \mathrm{лікування}$ у 93,75 \% вагітних спостерігали клінічне та бактеріологічне одужання. Відмічали достовірне збільшення кількості лактобацил у концентраціях понад $1 \times 10^{6} \mathrm{KУO} / \mathrm{мл}$.

Висновки. Вітчизняний кетоконазол лівагін-М є високоефективним засобом лікування генітального кандидозу у вагітних жінок та профрілактики внутрішньоутробного інтранатального інфрікування плода.

Ключові слова: кетоконазол; лівагін-М; вагітність; вагінальний кандидоз.

ПРИМЕНЕНИЕ ОТЕЧЕСТВЕННОГО КЕТОКОНАЗОЛА В ДОРОДОВОЙ ПОДГОТОВКЕ БЕРЕМЕННЫХ С ГЕНИТАЛЬНЫМ КАНДИДОЗОМ

Цель исследования - улучшение перинатальных последствий беременности и уменьшение количества акушерских осложнений у беременных с болезнями влагалища на основе применения отечественного кетоконазола (ливагин-М, Украина) в дородовой подготовке беременных с генитальным кандидозом и изучение его влияния на влагалищный микробиом.

Материалы и методы. Материалом исследования были показатели результатов бактериологического исследования влагалищного секрета 32 беременных с генитальным кандидозом и 15 здоровых беременных в 36-38 недель беременности. Методы исследования: клинические, биохимические, УЗД, бактериологические и медико-статистические.

Результаты исследования и их обсуждение У беременных, больных вагинальным кандидозом, были выявлены высокие титры грибов рода Candida - 1×105 КУО/мл у 28,12 \% беременных, $1 \times 10^{6}$ КУО/мл - у 53,13 \% женщин, более $1 \times 10^{7}$ КУО/мл - у 18,75 \% обследованных при резком уменьшении уровня лактобацилл - менее $1 \times 10^{6} \mathrm{KУO} / \mathrm{M} л$ у всех пациенток. После 10-дневного курса лечения у 93,75 \% беременных наблюдалось клиническое и бактериологическое выздоровление. Отмечалось достоверное увеличение количества лактобацилл в концентрациях более $1 \times 10^{6} \mathrm{KУO} / \mathrm{mл}$.

Выводы. Отечественный кетоконазол ливагин-М является высокоэффективным средством лечения генитального кандидоза у беременных женщин и профилактики внутриутробного интранатального иноицирования плода.

Ключевые слова: кетоконазол; ливагин-М; беременность; вагинальный кандидоз.

DOMESTIC KETOCONAZOLE ADMINISTRATION FOR PREPARTUM PREPARING OF THE PREGNANTS WITH GENITAL CANDIDOSIS

The aim of the study - improvement of pregnancy perinatal consequences and decrease of quantity of obstetrical complications in the pregnants with vaginal discharges based on the ground of domestic ketoconazole (Livagyn-M, Ukraine) administration for prepartum care to the pregnants with genital candidosis and research of its influence on vaginal microbiome.

Materials and Methods The material of research was indicators of vaginal secret bacteriological research results of 32 pregnants with vaginal candidosis and 15 healthy women in 36-38 weeks of pregnancy. The methods of the research were clinical, biochemical, ultrasound examination, microbiological and medico-statistical methods.

Results and Discussion The high fungi Candida concentrations: $1 \times 10^{5} \mathrm{CFU} / \mathrm{ml}$ in $28.12 \%$ pregnants, $1 \times 10^{6} \mathrm{CFU} / \mathrm{ml}-$ in $53.13 \%$ pregnants, more than $1 \times 10^{7} \mathrm{CFU} / \mathrm{ml}$ - in $18.75 \%$ of women were determined with important decrease of Lactobacillus spp. level - more than $1 \times 10^{6} \mathrm{CFU} / \mathrm{ml}$ in all patients. Clinical and bacteriological convalescence was in $93.75 \%$ of pregnants after 10-days treatment. Trustworthy increase of Lactobacillus spp. concentration has discovered.

Conclusions. Domestic ketokonazole Livagyn-M has high clinical efficiency in preparturital care to the pregnants with genital candidosis and prophylaxis of intrauteral intranatal fetus infection.

Key words: ketoconazole; livagyn-M; pregnancy; vaginal candidosis.

ВСТУП. Вагінальні інфекції є найчастішою патологією в структурі акушерсько-гінекологічної захворюваності в Україні та багатьох інших країнах світу [1-4]. Особливого значення набувають вагінальні інфекції в акушерській практиці, оскільки призводять до дисбіозу піхви, розви- тку акушерських ускладнень та внутрішньоутробного інфрікування плода, його інфрікування в пологовому каналі та розвитку післяпологових гнійно-септичних ускладнень [5-7]. До акушерських ускладнень відносять загрозу переривання вагітності, передчасні пологи, хоріоамніоніт, 
передчасний розрив плодових оболонок, народження дітей із малою масою тіла. У післяпологовому періоді характерним $€$ виникнення пуерперальної виразки та ендометриту.

Найбільш частими збудниками дисбіозу піхви під час вагітності є дріжджові гриби - Candida albicans, Candida crusei, Candida glabrata, а також їх поєднання з умовно-патогенною анаеробною кишковою мікробіотою [8]. Вагінальний кандидоз зустрічається при вагітності в 2-3 рази частіше, ніж у невагітних жінок, в силу змін рН піхви у бік кислого середовища. Крім цього, зниження клітинного імунітету на фоно гормональних змін теж сприяє розмноженню грибів у статевих шляхах вагітної. Значення грибкової інфекції в процесах висхідного інфікування плода активно вивчається, як і її негативний вплив на перебіг післяпологових гнійно-септичних ускладнень.

МЕТА ДОсЛІДЖЕННЯ - визначення ефективності застосування вітчизняного кетоконазолу лівагін-М виробництва Монфарм ПАТ (Україна) для проведення деконтамінації піхви перед пологами у вагітних із генітальним кандидозом 3 метою профрілактики контамінації плода в пологовому каналі та попередження післяпологових гнійно-септичних ускладнень.

МАТЕРІАЛИ ТА МЕТОДИ. БУЛо проведено клініколабораторне обстеження 32 вагітних віком 18-39 років із генітальним кандидозом та 15 вагітних із нормоценозом піхви, які перебували у відділенні патології вагітності лОКПЦу термін вагітності 36-38 тижнів. Діагноз було встановлено на основі анамнестичних даних, клінічних ознак, результатів лабораторного обстеження. Було проведено мікроскопічне та мікробіологічне обстеження, що включало культуральне дослідження секрету піхви з вивченням якісного та кількісного складу мікробіоти піхви із застосуванням тест-системи Гіносрлор-16. Залежно від стану мікробіоценозу піхви виділяли такі форми генітального кандидозу: 1) безсимптомне кандидоносійство, при якому відсутні клінічні прояви захворювання; дріжджоподібні гриби виявляли в низькому титрі (менше $10^{3}$ КУО/мл), а в складі мікробних асоціацій піхвової мікробіоти домінували лактобацили у відносно великій кількості (більше $10^{5}$ КУО/мл); 2) гострий кандидоз, при якому гриби виступали в ролі збудника, викликаючи клінічно виражену симптоматику захворювання; у піхвовій мікробіоті були присутні гриби роду Candida у високих титрах (більше $10^{4}$ КУО/мл) і знижені титри лактобацил (менше $10^{6}$ КУО/мл) при відсутності діагностично значимих титрів інших умовно-патогенних збудників; 3) хронічний рецидивний урогенітальний кандидоз - наявність 4-х і більше епізодів захворювання на рік до вагітності. Для профрілактики контамінації новонароджених грибами вагітним призначали препарат «Лівагін-М». Лівагін-М застосовується інтравагінально. Песарій глибоко вводиться у піхву. Курс лікування - одна вагінальна капсула (400 мг кетоконазолу) один раз на добу на ніч протягом 10 днів.

\section{СПИСОК ЛІТЕРАТУРИ}

1. Микроэкологические аспекты репродуктивного здоровья женщин и современные подходы кего поддержанию / Б. М. Венцковский, В. А. Товстановская, Д. С. Янковский, Г. С. Дымент // Здоровье женщины. -2002. - № 3 (11). - С. 86-91.
Кетоконазол є синтетичним похідним імідазолдіоксолану. Чинить виражену фунгіцидну та фуунгістатичну дію на дріжджові гриби (Candida spp., Pityrosporum spp., Cryptococcus spp. та ін.). Механізм його дії полягає в інгібуванні біосинтезу ергостеролу і зміні ліпідного стану мембрани грибів, що приводять до їх лізису. При інтравагінальному застосуванні лише незначна кількість кетоконазолу (менше 1 \%) потрапляє у системний кровотік. Максимальна концентрація у плазмі крові в жінок після інтравагінального застосування 400 мг кетоконазолу коливається в межах 0-10,7 нг/мл, що вважається слідовою, бо не чинить системної дії.

РЕЗУЛЬТАТИ ДОСЛІДЖЕННЯ ТА ЇХ ОБГОВОРЕННЯ. Аналізуючи перебіг вагітності в обстежених жінок, було встановлено, що при рецидивному кандидозі збільшувався відсоток загрози переривання вагітності (78,13 \%), плацентарної диссункції (71,88\%), дистресу плода $(53,13 \%)$. Спостерігали УЗД-ознаки внутрішньоматкового інфікування в різні терміни вагітності: багатоводдя (12,5 \% випадків), маловоддя (18,75 \% випадків), гіперплазія плаценти (3,12\%), кістозні та гіперехогенні включення в плаценті (25\%), пієлоектазія плода (34,38\%). При бактеріологічному дослідженні вагінальних виділень було виявлено високі титри грибів роду Candida - $1 \times 10^{5}$ КУО/мл у $28,12 \%$ вагітних, $1 \times 10^{6}$ КУО/мл - у 53,13 \% жінок, понад $1 \times 10^{7}$ КУО/мл -у 18,75 \% обстежених при різкому зниженні рівня лактобацил - менше $1 \times 10^{6} \mathrm{KУO} /$ мл у всіх пацієнток. У складі мікробних асоціацій у досліджуваній групі в невисоких титрах (10²-103 КУО/мл) висівали: епідермальний стафрілокок (9,37\%), кишкову паличку (12,5\%), Staph. aureus (6,25\%), Klebsiela pneumonia (3,12 \%), Enterobacter aeroginoza (6,25 \%) при абсолютному домінуванні грибів роду Candida (100 \%). Опитування пацієнток показало, що вже на 2-й день лікування мало місце покращення загального стану, зменшення кількості виділень із піхви. Після 10-денного курсу у більшості вагітних (93,75 \%) спостерігали повне клінічне одужання - зникали виділення, гіперемія, набряк слизової піхви, не було печіння й свербежу. У мазках та в бактеріологічних посівах піхвового секрету нитки міцелію та дріжджі були відсутні. Відмічали достовірне збільшення кількості лактобацил у концентраціях понад $1 \times 10^{6}$ КУО/мл.

ВИснОВКИ. 1. Вітчизняний кетоконазол лівагін-М $€$ високоефективним засобом лікування генітального кандидозу у вагітних жінок та профрілактики внутрішньоутробного інтранатального інсрікування плода.

2. Відсутність токсичного впливу на плід, зручність, комплаєнс у застосуванні дозволяють відносити вітчизняний лівагін-М до препаратів вибору проведення деконтамінації піхви перед пологами.

ПЕРСПЕКТИВИ ПОДАЛЬШИХ ДОСЛІДЖЕНЬ. ВИвчення стану піхвового мікробіому після закінчення післяпологового періоду в жінок, які хворіли на рецидивний вагінальний кандидоз та отримали лікування під час вагітності порівняно з відсутністю лікування. 
3. Белянин В. Л. Значение специфического и неспециорического звена иммунитета в развитии оппортунистических микозов / В. Л. Белянин, Р. А. Аравийский // Проблемы мед. микологии. - 2001. - Т. 3. - № 2. - С. 33-38.

4. Буданов П. В. Методы профрилактики, лечения и подготовки женщин с нарушениями микроценоза влагалища к родоразрешению и гинекологическим операциям / П. В. Буданов, М. А. Стрижакова // Акт. вопр. акуш., гинекол. и перинатол. - 2006. - Т. 5. - № 1. - С. 104-108.

5. Вдовиченко Ю. П. Сравнительные аспекты терапии вагинальных кандидозов / Ю. П. Вдовиченко, Е. С. Щербинская, В. В. Максимова // Здоровье женщины. - 2001. № 4. - C. 4-8.

\section{REFERENCES}

1. Ventskovskiy, B.M., Tovstanovskaya, V.A., Yankovskiy, D.S., \&Dyment, G.S. (2002). Mikroekologicheskie aspekty reproduktivnogo zdorovya zhenshchiny i sovremennye podkhody k ego podderzhaniyu [Microecological aspects of women reproductive health and contemporal doing to its support]. Zdorovye zhenshchiny - Woman's Health, 3 (11) 86-91 [in Russian].

2. Shunko, E.E., Yankovskyy, D.S., Dyment, H.S., \& Krasnova, Yu.Yu. (2004). Problemnye voprosy mikroekologii i antibakteryalnoy terapii novorozhdennykh s perynatalnoy patologiey [Problem questions of microbyology and antibacterial]. Zdorovye zhenshchiny - Woman's Health, 4 (20), 171-177 [in Russian].

3. Belyanin, V.L., \& Araviyskiy, R.A. (2001). Znachenie spetsyficheskogo i nespetsyficheskogo zvena immuniteta $v$ razvitii opportunisticheskikh mikozov. [Meaning of specific and unspecific parts of immunity in opportune mycosises]. Problemy med. Mikologii - Problems of Medical Micology, 3, 2, 33-38 [in Russian].

4. Budanov, P.V., \& Strizhakova, M.A. (2006). Metody profilaktiki, lecheniya i podgotovki zhenshchin s narusheniyami mikrotsenoza vlagalishcha $\mathrm{k}$ rodorazresheniyu i ginekologicheskim operatsiyam [The methods of prophylaxis,
6. Прилепская В. Н. Генитальный кандидоз. Современные подходы к лечению / В. Н. Прилепская // MRZ. - 1998. - № 5. - С. 5-6.

7. Прилепская В. Н. Особенности инорекционных процессов нижнего отдела половых путей. Возможности терапии препаратами для локального применения / В. Н. Прилепская // Вісн. Асоц. акушерів-гінекологів України. - 2002. - № 3. C. 50-54.

8. Местное лечение вагинального кандидоза во время беременности / [Д. Ю. Хофмейер, Д. П. Нейлсон, 3. Алфиревич и др.] // Кокрановское руководство: беременность и роды / под общей ред. Г. Т. Сухих ; пер. с англ. - М. : Логосфера, 2010. - С. 201-202.

treatment and preparing the women with vaginal microcenosis disorders to parturition and gynecological operations]. Akt. vopr. akush., ginekol. i perinatol., Nauch. Trudy - Urgent Issues of Obstetrics and Gynecology. Scientific Works. 5, 1, 104-108 [in Russian].

5. Vdovichenko, Yu.P., Shcherbinskaya, E.S., \& Maksimova, V.V. (2001). Sravnitelnye aspekty terapii vaginalnykh kandidozov [Compared aspects of vaginal candidosis therapy]. Zdorovye zhenshchiny - Woman's Health, 4, 4-8 [in Russian].

6. Prilepskaya, V.N. (1998). Genitalnyy kandidoz. Sovremennye podkhody k lecheniyu [Genital candidosis. Contemporal approach to treatment]. MRZ, 5, 5-6 [in Russian].

7. Prilepskaya, V.N. (2002). Osobennosti infektionnykh protessov nizhnego otdela polovykh putey. Vozmozhnosti terapii preparatami dlya lokalnogo primeneniya [Peculiarities of sex ways lower part infections. Treatment possibility by medicines for local implication]. Visn. Asots. akusheriv-hinekolohiv Ukrainy - Bulletin of Association of Obstetricians-genecologists, 3, 50-54.

8. Hofmayer, D.Yu., Nelson, D.P., \& Alfirevich, Z. (2010). Mestnoe lechenie vaginalnogo kandidoza vo vremya beremennosti: Kokranovskoe rukovodstvo: Beremennost i rody [Local treatment of vaginal candidosis in time of pregnancy: Cochrane Guide: Pregnancy and birth]. Sukhykh, G.T. (Ed.). Moscow: Logosfera [in Russian]. 